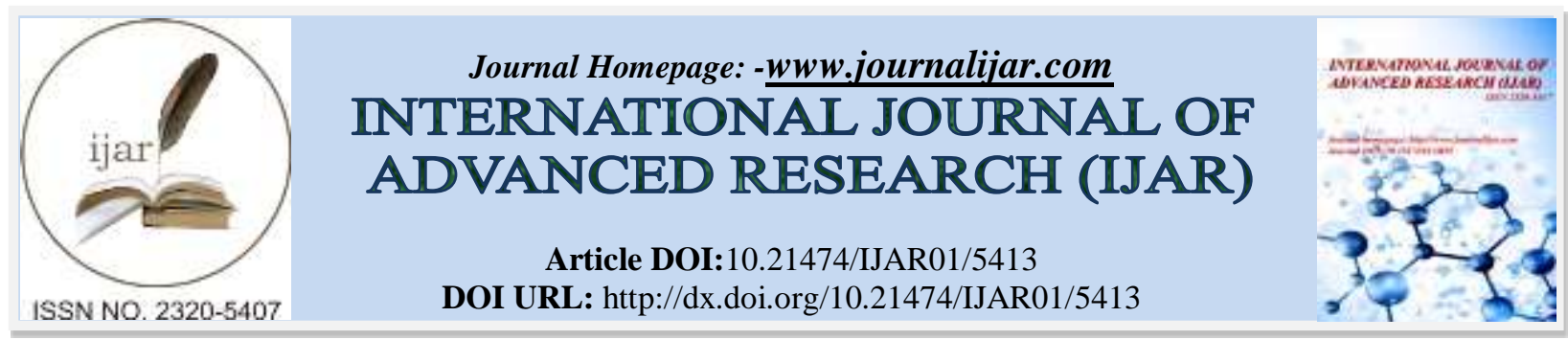

RESEARCH ARTICLE

\title{
ASSESSMENT OF HEAVY METAL RESIDUES IN EXCRETA OF BLUE ROCK PIGEON IN JAIPUR, RAJASTHAN.
}

\author{
Manju Bala ${ }^{1}$, Asha Sharma ${ }^{2}$ and Gaurav Sharma ${ }^{3}$. \\ 1. Department of Applied and Biosciences, Suresh GyanVihar University, Jaipur. \\ 2. Department of Zoology, Swargiya PNKS Government P.G. College Dausa, Rajasthan. \\ 3. Department of Microbiology, Suresh GyanVihar University.
}

\section{Manuscript Info \\ Manuscript History \\ Received: 12 July 2017 \\ Final Accepted: 14 August 2017 \\ Published: September 2017}

Key words:-

Atomic absorption spectrophotometer,

Heavy metals, excreta, non-invasive, industrial regions, environmental hazard

\begin{abstract}
Despite abated atmospheric emissions due to adoption of advanced technology in industrial operations and restrictions on emission, heavy metals may remain a major environmental hazard. The present study was focused to investigate the level of heavy metal pollution in excreta of blue rock pigeon collected from six different industrial regions in Jaipur. The concentrations of heavy elements were measured using atomic absorption spectrophotometer after chemical digestion with $\mathrm{HNO}_{3}$. Presence of heavy metals in excreta followed the order $\mathrm{Cd}<\mathrm{Pb}<$ $\mathrm{Ni}<\mathrm{Cr}<\mathrm{Cu}<\mathrm{Zn}$. Concentration of $\mathrm{Cr}(5.20 \pm 0.317$ to $19.40 \pm 3.89 \mathrm{ppm})$, $\mathrm{Pb}(0.22 \pm 0.030$ to $6.60 \pm 0.5 \mathrm{ppm})$ and $\mathrm{Ni}(1.92 \pm 0.135$ to $9.10 \pm 2.22$ $\mathrm{ppm})$ lies in toxic range while heavy elements such as $\mathrm{Cd}(0.185 \pm 0.007$ to $0.445 \pm 0.113 \mathrm{ppm}), \mathrm{Cu}(3.60 \pm 0.065$ to $26.05 \pm 0.721 \mathrm{ppm})$ and $\mathrm{Zn}$ $(31.98 \pm 10.10$ to $162 \pm 4.58 \mathrm{ppm})$ were found at nontoxic concentration in excreta samples. Thus concentrations of heavy metals recorded in the present studies suggested that birds are exposed to the high level of metal contamination in the environment which may have adverse effects on their health and also Excreta can be used as non-invasive method for biomonitoring the metal level in wild bird.
\end{abstract}

Copy Right, IJAR, 2017,. All rights reserved.

\section{Introduction:-}

Environmental pollution is one of the most devastating ecological crises facing the world today. It is especially true for most of the developing countries in South Asia, such as Pakistan, Nepal, Bangladesh, and India (Karn and Harada, 2001), where natural environment has been gradually contaminated as a consequence of urbanization and increasing use of fuels by households, vehicles besides this industrialization plays a key in role bringing certain environmental changes. In Rajasthan, Jaipur is located in the central part, is undergoing rapid urbanization and industrialization. Almost in all parts of Jaipur city and adjacent areas, a large number of industrial areas have been established during last two decades. With increased industrialization, heavy metal pollution has been reported as a major environmental problem. The term heavy metal refers to any metallic chemical element that has a relatively high density and is toxic or poisonous at low concentrations. For example copper, Manganese, Lead, Cadmium, Iron, Mercury, Zinc and Nickel (Raikwar et al., 2008). Although heavy metals are naturally occurring elements that are found throughout the earth's crust, most environmental contamination and their exposure result from anthropogenic activities such as mining, smelting operations and Industrial process which include metal processing 
in refineries, coal burning in power plants, petroleum combustion, nuclear power stations and plastics, textiles, microelectronics, wood preservation and paper processing plants.

Heavy metal toxicity is a major problem worldwide affecting both wild and captive avian populations, causing deaths in numerous bird species annually, resulting from the lack of baseline information of one species to another. Birds are exposed to heavy metal from drinking-water contamination (e.g. lead pipes), high ambient air metal concentrations near emission sources, or intake via the food. After absorption, metals circulate in the body, are excreted in fecal matter or get accumulated in various body tissues, or are sequestered in feathers (Nighat et al., 2013). Birds are the most conspicuous and significant component of different habitats due to their high sensitivity to environmental contaminants especially from anthropogenic activities than any other vertebrates, hence their presence or absence may indicate the ecological conditions of the particular area. Hence birds are the best to monitor environmental change (Kler et al., 2014 and Medona et al., 2015).

Excretion of heavy metals in fecal matter of birds has received attention because according to Wildlife Protection Act 1972, the capturing and killing of birds is legally banned by Govt. of India; therefore any analytical studies which make use of bird's tissues and organs are away from the experts working in this area. Besides, in India studies on heavy metal pollution in bird's excreta are restricted. As a further matter, the heavy metals show the capacity for bioaccumulation and biomagnification in the food chains (Zhuang et al., 2009). So the faecal matter as indicator of metal contamination has display the metal pollution level well in environment. Thus, faecal matter of bird is the only source, which if examined can give an estimation of the adverse impact of trace metals on these organisms and environment. Therefore, the present studies were designed in order to biomonitor concentration of heavy metals in the faecal matter of birds contributed by industrial environment and also to discover if faecal matter can be used as non-invasive method to determine metal concentration in environment.

\section{Materials and Methods:-}

\section{Study area:-}

Study areas include Jhotwara, Malviya, Mansarover, Sitapura, Vishwakarma industrial area and Sanganer industries of Jaipur, Rajasthan. Industrial effluent contributes to air, soil and water pollution by adding different types of contaminants. Some of the industries are situated inside the city and the remaining outside, but all are not free from human residential localities.

\section{Sample collection:-}

Dry excreta of bird's species Blue Rock Pigeon were collected from Jhotwara, Malviya, Mansarover, Sitapura, Vishwakarma industrial area and Sanganer industries of Jaipur, Rajasthan. Samples were collected in month of January and February (winter season) and in month of July and August (summer season) in 2016. Excreta Samples were collected from five different sites in each industrial area during both seasons. The collected excreta samples were put into polyethylene bags and labelled appropriately with the source, time and date of collection.

\section{Sample preparation:-}

0.5 gm dry excreta samples from different industrials areas were weighed. Concentrated nitric acid and Perchloric acid were added to each sample in 4:1 ratio. Samples were kept in water bath until it was digested completely and became clear. Perchloric acid was added (3 to 4 drops) to neutralize and to dissolve the fat. The final volume was made to $25 \mathrm{ml}$ with distilled water and the solution was filtered. Samples were stored at room temperature prior to analysis.

\section{Sample and Statistical analyses:-}

The digested samples were analyzed for heavy metals such as Cadmium (Cd), Chromium (Cr), Copper (Cu), Nickel $(\mathrm{Ni})$, Lead $(\mathrm{Pb})$, and Zinc $(\mathrm{Zn})$ by Atomic Absorption Spectroscopy (AAS) at Rajasthan state pollution control board, Jaipur. Each analysis was done three times while single blank was run for 5 samples. The readings taken on AAS were converted into parts per million $(\mathrm{ppm}=\mu \mathrm{g} / \mathrm{g})$. The data for different metals in different industrial areas during both seasons was statistically analysed by one way analysis of variance (ANOVA) succeeding Turkey HSD $(\mathrm{p}<0.05)$ deviation using the Statistical Packages of Social Science (SPSS) to determine whether heavy metals shows significant difference among the different industrial areas. The data obtained was represented as Mean $\pm \mathrm{SE}$ (standard error). 


\section{Results and Discussion:- \\ Metals concentration in fecal matter:-}

The elemental composition of excreta of Blue Rock Pigeon obtained from different industrial areas of Jaipur (Jhotwara, Malviya, Mansarover, Sitapura, Vishwakarma industrial areas and Sanganer industries) has shown the existence of six elements in total i.e. Cadmium $(\mathrm{Cd})$, Chromium $(\mathrm{Cr})$, Copper $(\mathrm{Cu})$, Nickel $(\mathrm{Ni})$, Lead $(\mathrm{Pb})$, and Zinc $(\mathrm{Zn})$ in present studies. $\mathrm{Cd}$ and $\mathrm{Pb}$ are included in the category of heavy metals which are toxic and non-essential in nature. As being essential elements, $\mathrm{Cr}, \mathrm{Ni}, \mathrm{Cu}$ and $\mathrm{Zn}$ are required to perform some metabolic activities in body. All these essential elements are also detrimental when exist above threshold levels in these organisms. All heavy metal concentrations observed shows variation among different industrial regions and also between seasons as it were evident from recorded data. In the present studies, Cadmium was not traceable in any sample in summer season and in samples from Jhotwara and Mansarover industrial area collected during winter seasons. Besides, lead was not detected in samples from Sitapura industrial area during winter season, while Copper, Chromium, Nickel and Zinc were found in miscellaneous concentration during both seasons as shown in Table 1 and Table 2. Thus, this variation in level of metals provides a range for all heavy metals concentration. The concentration of all heavy metals except Cd varied significantly at 5\% level of significance among the industrial regions (Table 1 and Table 2).

\section{Cadmium:-}

The Cd concentration in all industrial areas varied from ND to $0.445 \pm 0.113 \mathrm{ppm}$ and from ND to $0.225 \pm 0.055 \mathrm{ppm}$ in the winter and summer season respectively. Cd concentration was lowest in excreta sample of Sanganer industries and it was highest in Sitapura industrial area during summer season while in samples collected during winter season, Cd was present only in Sitapura industrial area.

\section{Lead:-}

The level of $\mathrm{Pb}$ was $\mathrm{ND}$ to $6.60 \pm 0.50 \mathrm{ppm}$ and from $0.22 \pm 0.03$ to $5.45 \pm 0.803 \mathrm{ppm}$ in the winter and summer season respectively for all industrial areas During winter season, concentration of $\mathrm{Pb}$ was found to be lowest in excreta sample collected from Mansarover industrial area and it was highest in Sanganer industries while lead concentration was highest in Vishwakarma and Mansarover industrial area and lowest in Sanganer industries during summer season.

\section{Chromium:-}

For all industrial areas, Cr concentration was $5.40 \pm 1.376$ to $16.55 \pm 2.0 \mathrm{ppm}$ and from $5.20 \pm 0.317$ to $19.40 \pm 3.89 \mathrm{ppm}$ in the winter and summer season respectively. Concentration of $\mathrm{Cr}$ significantly varies among six industrial areas during both seasons. Cr concentration was lowest in excreta collected from Sitapura industrial area and it was highest in Jhotwara industrial area during winter season. During summer season, highest chromium concentration was present in Malviya industrial area and lowest in Sanganer industries.

\section{Copper:-}

The $\mathrm{Cu}$ concentration, for all industrial areas, varied $6.55 \pm 2.40$ to $24.75 \pm 4.069 \mathrm{ppm}$ and from $3.60 \pm 0.065$ to $26.05 \pm 0.721 \mathrm{ppm}$ in the winter and summer season respectively. During winter season, $\mathrm{Cu}$ level was lowest in excreta collected from Mansarover industrial area and it was highest in Sitapura industrial area while its lowest value was recorded in Sitapura industrial area and highest value in Vishwakarma industrial area during summer season.

\section{Nickel:-}

The Ni concentration range was found to be $2.75 \pm 0.470$ to $9.10 \pm 2.22 \mathrm{ppm}$ and from $1.92 \pm 0.135$ to $6.45 \pm 0.310 \mathrm{ppm}$ in the winter and summer season respectively for all industrial areas. Ni level was lowest in excreta collected from Sanganer industries and it was highest in Vishwakarma industrial area during winter season. During summer season, highest nickel level was found in Jhotwara industrial area and lowest in Sanganer industries.

\section{Zinc:-}

Zn value varied from $49.60 \pm 8.11$ to $162 \pm 4.58 \mathrm{ppm}$ and from $31.98 \pm 10.10$ to $111.45 \pm 2.76 \mathrm{ppm}$ in the winter and summer season respectively among industrial areas. $\mathrm{Zn}$ concentration was lowest in excreta collected from Mansarover industrial area and highest in Vishwakarma industrial area during winter season while its lowest level has been observed in Jhotwara industrial area and highest in Sanganer industries during summer season. 
Table 1:-Concentrations of various heavy metals in the fecal samples of the different industrial areas, collected during month of January and February in 2016, of Jaipur (Rajasthan). The data is represented as mean \pm standard error of five samples of each industrial area.

\begin{tabular}{|l|l|l|l|l|l|l|}
\hline Metal & $\begin{array}{l}\text { Malviya } \\
\text { industrial } \\
\text { area }\end{array}$ & $\begin{array}{l}\text { Sanganer } \\
\text { industries }\end{array}$ & $\begin{array}{l}\text { Sitapura } \\
\text { industrial } \\
\text { area }\end{array}$ & $\begin{array}{l}\text { Vishwakarma } \\
\text { industrial } \\
\text { area }\end{array}$ & $\begin{array}{l}\text { Jhotwara } \\
\text { industrial } \\
\text { area }\end{array}$ & $\begin{array}{l}\text { Mansarover } \\
\text { industrial } \\
\text { area }\end{array}$ \\
\hline $\mathbf{C r}$ & $9.00 \pm 2.70^{*}$ & $6.00 \pm 0.927^{*}$ & $5.40 \pm 1.37^{*}$ & $14.4 \pm 0.447^{*}$ & $16.55 \pm 2.0^{*}$ & $13.75 \pm 4.32^{*}$ \\
\hline $\mathbf{C u}$ & $11.35 \pm 2.80^{*}$ & $7.50 \pm 1.83^{*}$ & $24.75 \pm 4.06^{*}$ & $11.5 \pm 3.60^{*}$ & $9.70 \pm 0.130^{*}$ & $6.55 \pm 2.40^{*}$ \\
\hline $\mathbf{N i}$ & $8.75 \pm 1.17^{*}$ & $2.75 \pm 0.470^{*}$ & $8.75 \pm 2.17^{*}$ & $9.10 \pm 2.22^{*}$ & $5.10 \pm 0.317^{*}$ & $3.95 \pm 1.025^{*}$ \\
\hline $\mathbf{P b}$ & $1.19 \pm 0.060^{*}$ & $6.60 \pm 0.50^{*}$ & $\mathrm{ND}$ & $1.33 \pm 0.401^{*}$ & $5.40 \pm 0.384^{*}$ & $0.71 \pm 0.216^{*}$ \\
\hline $\mathbf{Z n}$ & $129 \pm 9.70^{*}$ & $156 \pm 10.75^{*}$ & $148 \pm 12.14^{*}$ & $162 \pm 4.58^{*}$ & $76.45 \pm 3.25^{*}$ & $49.60 \pm 8.11^{*}$ \\
\hline $\mathbf{C d}$ & $0.425 \pm 0.063$ & $0.185 \pm 0.007$ & $0.445 \pm 0.113$ & $0.375 \pm 0.1$ & $\mathrm{ND}$ & $\mathrm{ND}$ \\
\hline
\end{tabular}

Significant difference among the industrial areas $(\mathrm{P} \leq 0.05), \mathrm{ND}=$ Not detectable

Table 2:-Concentrations of various heavy metals in the fecal samples of the different industrial areas, collected during month of July and August in 2016, of Jaipur (Rajasthan). The data is represented as mean \pm standard error of five samples of each industrial area.

\begin{tabular}{|l|l|l|l|l|l|l|}
\hline Metal & $\begin{array}{l}\text { Malviya } \\
\text { industrial } \\
\text { area }\end{array}$ & $\begin{array}{l}\text { Sanganer } \\
\text { industries }\end{array}$ & $\begin{array}{l}\text { Sitapura } \\
\text { industrial } \\
\text { area }\end{array}$ & $\begin{array}{l}\text { Vishwakarma } \\
\text { industrial area }\end{array}$ & $\begin{array}{l}\text { Jhotwara } \\
\text { industrial area }\end{array}$ & $\begin{array}{l}\text { Mansarover } \\
\text { industrial } \\
\text { area }\end{array}$ \\
\hline $\mathbf{C r}$ & $19.40 \pm 3.89^{*}$ & $5.20 \pm 0.317^{*}$ & $5.70 \pm 0.121^{*}$ & $13.65 \pm 0.377^{*}$ & $17.1 \pm 0.470^{*}$ & $15.60 \pm 1.84^{*}$ \\
\hline $\mathbf{C u}$ & $10.25 \pm 0.059^{*}$ & $4.70 \pm 1.14^{*}$ & $3.60 \pm 0.065^{*}$ & $26.05 \pm 0.721^{*}$ & $15.75 \pm 1.84^{*}$ & $17.70 \pm 5.62^{*}$ \\
\hline $\mathbf{N i}$ & $5.55 \pm 0.117^{*}$ & $1.92 \pm 0.135^{*}$ & $2.00 \pm 0.231^{*}$ & $6.25 \pm 0.410^{*}$ & $6.45 \pm 0.310^{*}$ & $6.35 \pm 1.28^{*}$ \\
\hline $\mathbf{P b}$ & $1.26 \pm 0.092^{*}$ & $0.22 \pm 0.03^{*}$ & $0.51 \pm 0.043^{*}$ & $5.45 \pm 1.71^{*}$ & $5.45 \pm 0.803^{*}$ & $1.185 \pm 0.058^{*}$ \\
\hline $\mathbf{Z n}$ & $84.2 \pm 8.78^{*}$ & $31.98 \pm 10.10^{*}$ & $50.3 \pm 10.63^{*}$ & $82.5 \pm 7.15^{*}$ & $111.45 \pm 2.76^{*}$ & $40.50 \pm 4.78^{*}$ \\
\hline $\mathbf{C d}$ & $\mathrm{ND}$ & $\mathrm{ND}$ & $0.225 \pm 0.055$ & $\mathrm{ND}$ & $\mathrm{ND}$ & $\mathrm{ND}$ \\
\hline
\end{tabular}

Significant difference among the industrial areas $(\mathrm{P} \leq \mathbf{0 . 0 5}), \mathrm{ND}=$ Not detectable

Toxic effects of heavy metals:-

According to Braune and Noble (2009) the concentration of heavy metals are usually low (1 ppm wet weight, which approximately represents $3 \mathrm{ppm}$ dry weight) in most living organisms. High $\mathrm{Cd}$ accumulation results in carcinogenic, mutagenic and tetratogenic effects. It alters the activity of a number of cellular enzymes. High concentration of $\mathrm{Cd}$ also causes altered behavior, suppression of egg production, egg shell thinning and testicular damage. According to Elinder CG (1992) cadmium is an environmental hazard and found that environmentally exposed organisms have suffered from kidney damage. In mammals and birds, cadmium accumulates in livers and kidneys at concentrations of $0.1-2 \mathrm{mg} / \mathrm{kg}$ and $1-10 \mathrm{mg} / \mathrm{kg}$ wet weight, respectively. Bravo et al. (2005) reported Cd level of $7.25 \mathrm{mg} / \mathrm{L}$ in plasma and high concentration i.e. $13.93 \mu \mathrm{g} / \mathrm{g}$ in excreta of black vulture (Coragyps atratus). High Cd levels near 20 ppm have been found associated with kidney damage in many bird species (Battaglia et al., 2005 and Toman et al., 2005). Thus the mean concentration of Cd which varied between ND and 0.445 ppm was not lies in toxic range in excreta of pigeon for all industrial areas under study. Kler et al. (2014) also reported low concentration of $\mathrm{Cd}(0.192 \pm 0.026 \mathrm{ppm})$ in excreta of blue rock pigeon.

Burger J (1995) examined the risk of lead to birds and found that Lead causes decreases in clutch and egg size, mortality of embryos and nestlings, depression of growth and deficits in behaviour that affect survival. Lead decreases migratory behaviour and increases vulnerability to cold stress, hunters and other predators. Dauwe et al. (2005) reported that $\mathrm{Pb}$ impairs the growth and survival of nestlings, causes haemolytic anaemia in wild $\mathrm{Pb}$ poisoned birds and has adverse effects on reproduction such as decreased plasma calcium, egg production and also causes behavioural impairments. Further, Jayakumar and Muralidharan (2011) recorded the maximum concentrations of $\mathrm{Pb}(20.59 \pm 9.07 \mu \mathrm{g} / \mathrm{g})$ in muscles of jungle babbler which falls in the toxic category. Lead at its 4 ppm concentration in feathers cause adverse effects in birds (Burger and Gochfeld, 2000b). Thus, mean Pb concentration varied from ND to $6.60 \pm 0.50 \mathrm{ppm}$ in the excreta of pigeon from different industrial area in both seasons was above this value indicating high exposure of $\mathrm{Pb}$ to the birds. The high concentration of $\mathrm{Pb}$ in excreta can be related to the different anthropogenic activities. A concentration of $5.753 \pm 0.676 \mathrm{ppm}$ of $\mathrm{Pb}$ in excreta of blue rock pigeon was reported by Kler et al. (2014). 
It observed that industrial activities e.g. metal plating, dyes, pigments, ceramic; glues, tanning, wood preserving contribute to $\mathrm{Cr}$ level in environment (Alloway, 1995). Kler et al. (2014) recorded the concentration of $\mathrm{Cr}$ in excreta of blue rock pigeon in the range of $6.747 \pm 1.373 \mathrm{ppm}$. According to Burger and Gochfeld (2000a) Cr concentration of $2.8 \mu \mathrm{g} / \mathrm{g}$ in bird's feathers might be associated with adverse effects. Studies by Malik and Zeb (2009) showed high Cr concentration $(6.6-7.12 \mu \mathrm{g} / \mathrm{g})$ in feathers of cattle egret. Thus, in present studies, $\mathrm{Cr}$ occurs at high level $(5.20 \pm 0.317$ to $19.40 \pm 3.89 \mathrm{ppm})$ in excreta of blue rock pigeon and harmful to these organisms. According to Kerte'sz and Fa'ncsi (2003) high Cr level produces adverse effects on embryonic development, hatching and viability of the mallard.

Carpenter et al. (2004) found that at high doses, essential elements, such as $\mathrm{Cu}$ and $\mathrm{Zn}$ could also have toxic effects on kidneys and impair reproduction. Higher levels of chromium causes decrease in relative mass of kidney, lung and heart to body mass (Fiaz Ahmad, 2004). Bravo et al. (2005) reported Cu level $20.26 \mu \mathrm{g} / \mathrm{g}$ in excreta of black vulture (Coragyps atratus) lies in nontoxic range. More than $100 \mu \mathrm{g} / \mathrm{g}$ of $\mathrm{Cu}$ in liver tissues of mute swan did not exhibit any sign of $\mathrm{Cu}$ toxicity (Jayakumar and Muralidharan, 2011). Henderson and Winterfield (1975) found that $\mathrm{Cu}$ concentrations of 187 to $323 \mu \mathrm{g} / \mathrm{g}$ caused acute poisoning in liver of Canada goose. Therefore, in present studies the concentration of $\mathrm{Cu}(3.60 \pm 0.0653$ to $26.05 \pm 0.7212 \mathrm{ppm})$ was below the toxic range in excreta, collected from all industrial areas in both seasons. Kler et al. (2014) also found that concentration of $\mathrm{Cu}$ in excreta of blue rock pigeon lies in nontoxic range $(119.47 \pm 52.60 \mathrm{ppm})$.

L. Millaku et al. (2015a) found that Ni cause histopathological changes in the testes and also alters blood parameters of birds such as decreased enzymatic activity, decreased blood protein content etc. However, Bravo et al. (2005) reported $\mathrm{Ni}$ concentration $15.19 \mu \mathrm{g} / \mathrm{g}$ in excreta of black vulture while Kaur and Dhanju (2013) reported $\mathrm{Ni}$ concentration of $6.26-12.25 \mu \mathrm{g} / \mathrm{g}$ in excreta of blue rock pigeon. Malik and Zeb (2009) reported the toxic $\mathrm{Ni}$ concentration varied from $7.8 \mu \mathrm{g} / \mathrm{g}$ to $9.0 \mu \mathrm{g} / \mathrm{g}$ in feathers of cattle egret from Pakistan, thus depicting the high exposure of $\mathrm{Ni}$ to pigeons in Malviya industrial area $(8.75 \pm 1.17 \mathrm{ppm})$, Sitapura industrial area $(8.75 \pm 2.17 \mathrm{ppm})$ and Vishwakarma industrial area $(9.10 \pm 2.22 \mathrm{ppm})$. Anthropogenic sources of nickel include industrial waste or combustion of fuel (Bhagure and Mirgane, 2010).

Bravo et al. (2005) reported Zn concentration of $202.57 \mu \mathrm{g} / \mathrm{g}$ in excreta of black vulture (Coragyps atratus) while Kaur and Dhanju (2013) reported high concentration of $\mathrm{Zn}$ in excreta of blue rock pigeon in range of 54.49 - 475.00 ppm. Several cases of $\mathrm{Zn}$ toxicosis have been seen in Hispaniolan Amazon parrots (Amazona vertralis) with liver zinc levels ranging from 110 to $359 \mu \mathrm{g} / \mathrm{g}$ wet weight (Lewis et al., 2001). According to Van wyk et al. (2001) normal $\mathrm{Zn}$ levels in birds vary between 100 and $200 \mu \mathrm{g} / \mathrm{g}$. From these observations it can be concluded that level of $\mathrm{Zn}$ detected in excreta of blue rock pigeon from all industrial areas under study indicates no risk to these species.

\section{Conclusion:-}

Thus it can be concluded that beingness of heavy metals in excreta of pigeon in all the six industrial regions make fecal matter an appropriate indicator for the determination of heavy metal contamination in wild birds without scarifying them. Further among the industrial regions, the evidential variations in metal level throw light on the fact that bird's habitat shows significant alterations in the level of contamination of the environment which may be attributed to the different industrial operations that occurs among different industrial regions. Pollutant concentration detected during present study from fecal sample of pigeon in industrial regions of Jaipur might indicate that regular monitoring, proper management and control of these metals in the environment is required.

\section{Acknowledgement:-}

A special thanks to Dr. Asha Sharma, professor of Zoology and Dr. Gaurav Sharma, professor of Microbiology for their guidance through all the phases of this research work and author is also great full of the Suresh GyanVihar University, Jaipur and Rajasthan state pollution control board, Jaipur for providing necessary facilities to carry out the present research work.

\section{References:-}

1. Ahmad, F., Muhammad, T.J., Mansoor, A.S. and Kausar. R. (2004): Effects of higher levels of chromium and copper on broiler health and performance during the peak tropical summer season. Vet. Arhiv., 74(5): $395-408$.

2. Alloway, B.J. (1995). Heavy Metals in Soils, 2nd Ed, Blackie Academic and Professional, an Imprint of Chapman and Hall, London. 
3. Battaglia, A., Sergio, G., Giorgio, C. and Roberto, S. (2005): Heavy metal contamination in little owl (Athene noctua) and common buzzard (Buteo buteo) from northern Italy. Ecotoxicol. Environ. Saf., 60: 61-66.

4. Bhagure G.R. and Mirgane, S.R (2010): Heavy Metal Concentrations in Ground Waters and Soils of Thane Region of Maharashtra, India. Environ. Monit. Assess, 173 (1-4): 643-652.

5. Bravo, A., Marinela, C., Azuero, S. and Salas, R. (2005): Heavy metal levels in plasma and faecal material samples of the black vultue (Coragyps atratus). Revista. Clentif. 15: 319-325.

6. Braune, B. and Noble, D. (2009): Environmental contaminants in Canadian shorebirds. Environ. Monit. Assess, 148: $185-311$.

7. Burger J. (1995): A risk assessment for lead in birds. J Toxicol Environ Health Journal, 45: 369-396.

8. Burger, J. and Gochfeld, M. (2000a): Metal levels in feathers of 12 species of seabirds from Midway Atoll in the northern Pacific Ocean. Sci. Total Environ, 257(1): 37-52.

9. Burger, J. and Gochfeld, M. (2000b): Effects of lead on birds (Laridae): A review of laboratory and field studies. J. Toxicol. Environ. Health, 3(2): 59-78.

10. Carpenter, J. W., Andrews, G. A. and Beyer, W. N. (2004): Zinc toxicosis in a free-flying trumpeter swan (Cygnus buccinator), J. Wildl. Dis., 40: 769-774.

11. Dauwe, T., Janssens, E., Pinxten, R. and Eens, M. (2005): The reproductive success and quality of blue tits (Parus caeruleus) in a heavy metal pollution gradient. Environ. Pollut, 136(2): 243-251.

12. Elinder, C.G. (1991): Cadmium as an environmental hazard. IARC Sci Publ., 118: 123-132.

13. Henderson, B.M. and Winterfield, R.W. (1975): Acute copper toxicosis in the Canada goose. Avian. Dis., 19: 385-387.

14. Jayakumar, R. and Muralidharan, S. (2011): Metal contamination in select species of birds in Nilgiris district, Tamil Nadu, India. Bull. Environ. Contam. Toxicol., 87: 166-170.

15. Kaur, N. and Dhanju, C.K. (2013): Heavy metals concentration in excreta of free living wild birds as indicator of environmental contamination. The Bioscan, 8(3): 1089-1093.

16. Karn, S.K. and Harada, H. (2001): Surface water pollution in three urban territories of Nepal, India, and Bangladesh. Environ. Manage, 28(4): 483-496.

17. Kerte'sz, V. and Fa'ncsi, T. (2003): Adverse effects of (surface water pollutants) $\mathrm{Cd}, \mathrm{Cr}$ and $\mathrm{Pb}$ on the embryogenesis of the mallard. Aquat. Toxicol., 65: 425-433.

18. Lewis, C. A., Poppenga, R. J., Davidson, W. R., Fischer, J. R. and Morgan, K. A. (2001): Lead toxicosis and Trace elements levels in wild birds and mammals at Firearms training facility. Arch. Environ. Contam. Toxicol. 41: 208-214

19. Lulzim, M., Imeri, R., and Trebicka, A. (2015a): Histopathological changes in testes of house sparrow (Passer domesticus). J. Mater. Environ. Sci., 6(5): 1292-1296.

20. Malik, R. N. and Zeb, N. (2009): Assessment of environmental contamination using feathers of Bubulcus ibis L. as a biomonitor of heavy metal pollution, Pakistan. Ecotoxicology, 18: 522-536.

21. Medona Mary, R., Nirmala, T. and Delphine Rose, M.R. (2015): Feeding guild and diversity of avifauna at sothuparai reservoir, Periyakulam, Theni district, Tamilnadu, India. Int J RecentSci Res., 6(12): 7997-8001.

22. Raikwar M.K., Kumar P., Singh M. and Singh A. (2008): Toxic effect of heavy metals in livestock health, Vet World., 1(1): 28-30.

23. Shagufta, N., Shahid, I., Muhammad, S.N., Mahmood, T. and Shah, S. I. (2013): Estimation of heavy metal residues from the feathers of Falconidae, Accipitridae, and Strigidae in Punjab, Pakistan. Turk J Zool., 37: 488500 .

24. Tejdeep, K.K., Vashishat, N. And Kumar, M. (2014): Heavy metal contamination in excreta of avian species from Ludhiana district of Punjab. Int. J. Adv. Res., 2(7): 873-879.

25. Toman, R., Massanyi, R., Lukae, N., Ducsay, L. and Golian, J. (2005): Fedility and content of cadmium in pheasant (Phasianus colchicus) following cadmium intake in drinking water. Ecotoxicol. Environ. Saf., 62: 112117.

26. Van Wyk, E., Van der Bank, F.H., Verdoorn, G.H. and Hofmann, D. (2001): Selected mineral and heavy metal concentrations in blood and tissues of vultures in different regions of South Africa. South African J. Anim Sci., 31(2): 57-63.

27. Zhuang, P., Zou, H. and Shu, W. (2009): Biotransfer of heavy metals along a soil-plant insect- chicken food chain: Field study. J. Environ. Sci., 21(6): 849-853. 